International

Medical Society

http://imedicalsociety.org

\title{
Religiosity and Hope in Patients with Chronic Renal Failure: Coping Strategies
}

\author{
Geórgia Alcântara Alencar Melo', Renan Alves Silva1, Maria Francisca Costa da Silva², \\ Marli Teresinha Gimeniz Galvão ${ }^{3}$, Viviane Martins da Silva ${ }^{3}$, Joselany Áfio Caetano ${ }^{3}$
}

\section{Abstract}

Objective: Describe the level of hope and religiosity of patients with chronic renal disease through the Herth Hope Scale and Duke Religiosity Scale and analyze how they correlate.

Method: Exploratory, cross-sectional study conducted with 62 patients. The Spearman correlation coefficient was used to assess the relationship between the scales.

Results: Hope obtained a mean score of 39 points and intrinsic religiosity, 13.14. Among the scales, statistically significant correlation was found between the items "optimism" with attendance to the religious temple $(p=0.016)$, beliefs and my way of living $(p=0.008)$ and effort to live up to the religion ( $p=0.008$ ); "strength" with effort to live up to the religion ( $p=0.043$ ); "ability to give and receive affection" with attendance to the religious temple (0.050), my religious beliefs are what really lie behind my whole approach to life $(p=0.014)$ and I try hard to carry my religion over into my life $(p=0.032)$.

Conclusion: Religiosity is a positive tool for coping with the healthdisease process.

\section{Introduction}

Chronic kidney disease is considered a public health problem in Brazil, in view of the high morbidity and mortality, and the high cost involved in the treatment [1]. There is a growing number of CKD patients undergoing dialysis. In 2010, there were 49,077 patients with chronic renal failure, and in 2014 the number increased to 112,004 [2].
1 RN, Master's Degree Student, Graduate Program in Nursing, School of Nursing, Federal University of Ceara. Fortaleza, Ceará, Brazil.

2 RN, Graduated in Nephrology. Patos, Paraíba State, Brazil

3 RN, PhD, Professor, School of Nursing, Federal University of Ceará. Fortaleza, Ceará State, Brazil.

\section{Contact information:}

Geórgia Alcântara Alencar Melo.

"' Georgiaenf@hotmail.com

\section{Keywords}

Hope; Religion; Chronic Renal Failure. 
Thus, the exponential increase of the disease and the impact in the spheres of personal and professional life of the individual, as well as complex therapeutic regimens and significant changes in activities of daily living turn feelings of hopelessness expected among patients with this disease.

Thus, patients commonly develop mechanisms or behaviors to cope with the illness and/or the dialysis, and these are important to their bio-psychospiritual well-being. Increased religiosity is one of such mechanisms that enable the search for meaning to deal with life and that reduce the feeling of hopelessness; positively impacting on better days, since this clinical condition represents an extremely challenging situation [3].

Religiosity contributes to coping with adverse health situations by assigning meanings to the reformulation of the understanding of the life length, and is a resource for changes in health and suffering [4].

A coping strategy that is intrinsically related to religion is hope, since it drives the individual to act, move and achieve goals and accomplish the objectives of the prescribed treatment. The lack of hope can leave the individual without perspective, just waiting to passively die. Although hope does not have the power of healing, it imparts encouragement to the patient to continue to fight and pursue clinical improvements [5].

Hope and religiosity are the focus of researches on health and tools for their evaluation have been developed. A research carried out in the Cinahl, PubMed and Scopus databases to identify instruments to measure hope and religiosity in patients with chronic diseases found the scales Herth Hope Index $(\mathrm{HHI})$, Hert Hope Scale $(\mathrm{HHS})$; and the Brief Multidimensional Measure of Religiousness/Spirituality, World Health Organization Quality of Life Instrument - Spirituality, religion and personal beliefs (WHOQOL- SRPB), Attitude Toward Christianity Scale, Age Universal Religious Orientation, Intrinsic Religious Motivation Scale, Christian Religious Inter- nalization Scale, Spiritual Well-Being, The Behavioral Religiosity Scale and the Duke Religiosity Scale (DUREL).

The Herth Hope Scale has North American origin and has as objective to quantify the life expectancy of the patient. It has rapid application and it is easy to understand and had cross-cultural adaptation and validation for the Brazilian Portuguese [6], showing good reliability with Cronbach's alpha (0.72) in patients undergoing chronic renal dialysis [7].

In turn, the Duke Religiosity Scale (DUREL) has been adapted and validated [8]and has good reliability measures with Cronbach's alpha of 0.88 ; and Spearman correlation coefficients between the domains of organizational (OR) and non-organizational (NOR) religiosity [9].

In Brazil, hope andreligiousity have been studied in patients undergoing hemodialysis [7, 10-11]. However, these did not show the correlation between the HHS and DUREL scales, and it was this gap that motivated the present study, assuming that religion is a coping mechanism for improvement of hope.

Given the above, the objectives of this study were to describe the level of hope and religiosity of adult patients with chronic renal disease through HHS and DUREL scales, and analyze how these are correlated.

\section{Method}

This is a descriptive, exploratory and cross-sectional studyheld in a Renal Replacement Therapy Unit in the state of Paraíba-PB, Brazil, from June to July 2015.

Based on a total population of 75 people registered and followed in the unit, 62 patients were included in the study. The Inclusion criteria were: age above 18 years, be registered and accompanied by the nephrology unit, present cognitive ability to respond to the instrument and be undergoing hemodialysis for at least six months. Exclusion criteria were: present difficulties in understanding, and 
unstable clinical status and/or hemodynamics. Based on these, 13 patients were excluded, one for having listening impairment; seven for being under treatment for less than six months; two for being hemodynamically unstable and three because they refused the participation.

Data was collected through interviews during hemodialysis sessions. To this end, questionnaires were used. These had questions covering sociodemographic characteristics (age, sex, level of education, marital status, income, religion); clinical conditions (dialysis time); Hope Herth Scale (HHS) and Duke Religiosity Scale (DUREL).

The HHS is composed of the 12 Likert-type items with four points. The total score ranges from 12 to 48 , and the higher the score the higher level of hope [6]. Studies show that, based on patients with various medical conditions, the median was 36 points [12-13].

The Duke Religiosity scale (DUREL) has five items that capture three of the religious dimensions that are most related to health outcomes: organizational $(\mathrm{OR})$, non-organizational (NOR) and intrinsic religiosity (IR). The first dimension (item 1) is related to Organizational Religiosity (OR), which involves the frequency of attendance to religious gatherings such as church services, worship, ceremonies and groups of study or prayer. The second dimension (item 2) deals with the Non-organizational Religiosity (NOR), i.e., the religiosity related to the more introspective activities, such as prayer, meditation, reading religious texts, listen to or watch religious programs on TV or radio. In the first two dimensions, the scores can range from 1 to 6 . The third dimension consists in religiosity in itself, so called Intrinsic Religiosity (IR), addressing the items 3 to 5. The scores of this dimension range from 3 to 15 .

In the analysis of results of the DUREL, scores on all three dimensions (OR, NOR and IR) must be analyzed separately, and their scores must not be summed for a total score. On this scale, the response options of the last three items are in a Likert-type scale, derived from the scale of 10 items of the intrinsic religiosity of Hoge [8].

For the analysis of religiosity scale, a reversal of the scores of all items was performed with the aim of achieving a positive convergence between the scales, since the higher the religiosity, the greater is expected to be the hope.

Data were analyzed using descriptive statistics using the SPSS statistical package version 20.0. Measures of central tendency (average, minimum and maximum) and spread (standard deviation) were calculated, and the Spearman correlation coefficient was used to assess the relationship between the HHS and DUREL.

The study met the ethical standards of national and international studies.

\section{Results}

The time of dialysis was 5.2 years in average. Most patients were male (51.6\%), Catholic (72.6\%), aged between 41 and 60 years (mean $=50$ years). Among them, $46.8 \%$ reported to be white, with a mean of 7.6 years of schooling (range $0-19$ years), in situation of active labor (51.6\%), earning up to one minimum wage (88.7\%). Regarding marital status, $53.2 \%$ had a partner; and less than half (45.2\%) had a companion during hemodialysis sessions.

An average score of 39 points for HHS was observed. The variation of the total score achieved was 32-46. In relation to the variation of scores in the items, none of the patients "completely disagreed" the statements of items: 1 (I am optimistic about life), 4 (I can see possibilities in the midst of difficulties), 5 (I have a faith that comforts me), 7 (I can remember happy and pleasant times) and 12 (I feel my life has value and usefulness) (Table 1).

As for the assessment of the items, those who had lower average scores were the item 2 (I have short and/or long range plans) with a mean value of 2.81 ( \pm 0.99$)$ and the item 10 (I have a sense of direction) with a value of $2.84( \pm 0.71)$. 
Table 1. Description of the measures of central tendency and spread of responses of patients of a Renal Replacement Therapy Unit ( $\mathrm{n}=$ 62) to the Herth Hope Scale . Patos, Paraíba, Brazil. 2015.

\begin{tabular}{|l|l|c|c|}
\hline \multicolumn{1}{|c|}{ Variables } & Mean & $\begin{array}{c}\text { Standard } \\
\text { deviation }\end{array}$ \\
\hline 1 & I have a positive outlook toward life & 3.06 & 72 \\
\hline 2 & I have short and/or long range plans & 2.81 & 0.99 \\
\hline 3 & I feel all alone & 3.27 & 0.87 \\
\hline 4 & I can see possibilities in the midst of & 3.03 & 0.40 \\
\hline difficulties & & \\
\hline 5 & I have a faith that gives me comfort & 3.61 & 0.52 \\
\hline 6 & I feel scared about my future & 3.06 & 0.81 \\
\hline 7 & I can recall happy/joyful times & 3.39 & 0.55 \\
\hline 8 & I have deep inner strength & 3.31 & 0.76 \\
\hline 9 & $\begin{array}{l}\text { I am able to give and receive caring/ } \\
\text { love }\end{array}$ & 3.56 & 0.62 \\
\hline 10 & I have a sense of direction & 2.84 & 0.71 \\
\hline 11 & I believe that each day has potential & 3.53 & 0.59 \\
\hline 12 & I feel my life has value and worth & 3.50 & 0.54 \\
\hline Total Hope & 39 & 3.42 \\
\hline
\end{tabular}

Table 2. Description of the measures of central tendency and spread of responses of patients of a Renal Replacement Therapy Unit ( $\mathrm{n}=$ 62) to the Duke Religiosity Scale. Patos, Paraíba, Brazil. 2015

\begin{tabular}{|l|l|c|c|}
\hline \multicolumn{1}{|c|}{ Variables } & Mean & $\begin{array}{c}\text { Standard } \\
\text { deviation }\end{array}$ \\
\hline 1 & $\begin{array}{l}\text { How often you go to a church, } \\
\text { temple or other religious meeting }\end{array}$ & 3.82 & 1.41 \\
\hline $\begin{array}{l}\text { How often do you spend your time } \\
\text { with individual religious activities }\end{array}$ & 4.61 & 1.58 \\
\hline $3 \begin{array}{l}\text { In my life, I experience the presence } \\
\text { of God (or the Holy Spirit). }\end{array}$ & 4.87 & 0.34 \\
\hline $\begin{array}{l}\text { My religious beliefs are what really } \\
\text { lie behind my whole approach to life }\end{array}$ & 4.18 & 0.78 \\
\hline $\begin{array}{l}\text { I try hard to carry my religion over } \\
\text { into all my other dealings in life. }\end{array}$ & 4.10 & 0.88 \\
\hline Domains & 13.14 & 1.42 \\
\hline Intrinsic religiosity &
\end{tabular}

In contrast, the items with higher scores were the item 5 (I have a faith that gives me comfort), with a total average score of $3.61( \pm 0.52)$ and item 9 (I am able to give and receive caring/love), with a mean value of $3.56( \pm 0.62)$.

Regarding religion, the item with the highest score was "I feel the presence of God or the Holy Spirit in my life", with an average score of 4.87 ( \pm 0.33$)$; followed by "How often do you spend your time with individual religious activities" with a score of $4.61 \pm 1.58$. Still, it was observed that the item: "My religious beliefs are behind my whole way of life" had an average score of 4.18 ( \pm 0.78 ) (Table 2 ).

In this study, the minimum score was 1 and maximum score was 6 , with the first dimension showing an average of $3.82( \pm 1.41)$, the second dimension, a mean of $4.61( \pm 1.58)$ and the third dimension, the minimum score was nine and the maximum was fifteen, with an average of $13.14( \pm 1.42)$. The dimension with the highest score was non-organizational religiosity. This behavior was observed due to the practice of religious activities in private, because of the physical limitations imposed by the disease, making it difficult to the person participate in community events.

The Spearman correlation test was used to check the relationship between the scales of religiosity and hope and some items were significantly correlated. Item 1 of the Duke Religiosity Scale (How often do you go to a church, temple or other religious meeting) showed a statistically significant correlation with the items: optimism ( $p=0.016)$ and the ability to give and receive affection $(p=0,05)$ of the Herth Scale (Table 3).

Item 4 of the DUREL scale (My religious beliefs are what really lie behind my whole approach to life) showed a statistically significant correlation with the items: optimism ( $p=0.008)$, ability to give and receive affection ( $p=0.014)$ and destiny $(p=0.006)$ of the HHS (Table 3).

The last item on the DUREL scale that showed a statistically significant correlation was (I try hard to 
carry my religion over into all my other dealings in life) with the items: optimism $(p=0.007)$, strength $(p=0.04)$ ability to give and receive affection ( $p=$ 0.03 ) and destiny ( $p=0.002$ ) of the HHS (Table 3).

\section{Discussion}

Based on the results found in this study, it is observed that patients with chronic renal disease have good levels of hope, and this might lead them to travel long distances in search of treatment for their illness; to submit to the relentless invasive procedu-

Table 3. Correlation between the items of the Hert Hope Scale and Duke Religiosity Scale as responded by patients assisted in a Renal Replacement Therapy Unit $(n=62)$. Patos, Paraíba, Brazil. 2015.

\begin{tabular}{|c|c|c|c|c|c|c|}
\hline \multicolumn{2}{|c|}{ Hert Hope Scale } & \multicolumn{5}{|c|}{ Duke Religiosity Scale } \\
\hline \multicolumn{2}{|c|}{ Items } & $\begin{array}{l}\text { Frequency of } \\
\text { attendance to } \\
\text { the religious } \\
\text { temple }\end{array}$ & $\begin{array}{l}\text { Individual } \\
\text { activities }\end{array}$ & $\begin{array}{c}\text { Presence of } \\
\text { God }\end{array}$ & $\begin{array}{c}\text { Beliefs rule the } \\
\text { way of life }\end{array}$ & $\begin{array}{l}\text { Effort to live } \\
\text { up to the } \\
\text { religion }\end{array}$ \\
\hline \multirow{2}{*}{ Optimism } & Pearson's coefficient & $0.305^{\star}$ & 0.152 & 0.041 & 0.333 & $0.340 *$ \\
\hline & P-value & $(0.016)$ & $(0.239)$ & 0.753 & $(0.008)$ & $(0,007)$ \\
\hline \multirow{2}{*}{$\begin{array}{l}\text { Plans in short and } \\
\text { long term }\end{array}$} & Pearson's coefficient & 0.129 & -0.124 & -0.027 & 0.093 & 0.196 \\
\hline & P-value & $(0.317)$ & $(0.338)$ & 0.836 & 0.474 & 0.128 \\
\hline \multirow{2}{*}{ Social living } & Pearson's coefficient & 0.155 & -0.105 & 0.137 & 0.052 & 0.064 \\
\hline & P-value & $(0.231)$ & $(0.418)$ & $(0.288)$ & $(0.686)$ & $(0.619)$ \\
\hline \multirow{2}{*}{$\begin{array}{l}\text { Possibilities in the } \\
\text { midst of difficulties }\end{array}$} & Pearson's coefficient & 0.056 & -0.084 & 0.029 & 0.105 & 0.039 \\
\hline & P-value & $(0.664)$ & $(0.519)$ & $(0.820)$ & $(0.417)$ & $(0.763)$ \\
\hline \multirow{2}{*}{ Comfort by faith } & Pearson's coefficient & 0.058 & 0.183 & 0.193 & 0.037 & 0.087 \\
\hline & P-value & $(0.657)$ & $(0.154)$ & $(0.132)$ & $(0.773)$ & $(0.501)$ \\
\hline \multirow{2}{*}{ Boldness } & Pearson's coefficient & 0.093 & 0.065 & -0.006 & 0.097 & 0.019 \\
\hline & P-value & $(0.471)$ & $(0.616)$ & $(0.964)$ & $(0.452)$ & $(0.883)$ \\
\hline \multirow{2}{*}{$\begin{array}{l}\text { Memory of } \\
\text { happy times }\end{array}$} & Pearson's coefficient & 0.132 & -0.125 & -0.074 & -0.042 & 0.108 \\
\hline & P-value & $(0.308)$ & $(0.335)$ & $(0.568)$ & $(0.746)$ & $(0.405)$ \\
\hline \multirow{2}{*}{ Strength } & Pearson's coefficient & 0.127 & -0.246 & 0.095 & 0.127 & $0.258^{*}$ \\
\hline & P-value & $(0.325)$ & $(0.054)$ & $(0.460)$ & $(0.327)$ & $(0.043)$ \\
\hline \multirow{2}{*}{$\begin{array}{l}\text { Ability to give and } \\
\text { receive affection }\end{array}$} & Pearson's coefficient & $0.251^{\star}$ & 0.238 & 0.076 & $0.312^{*}$ & $0,273^{*}$ \\
\hline & P-value & $(0.050)$ & $(0.063)$ & $(0.558)$ & $(0.014)$ & $(0.032)$ \\
\hline \multirow{2}{*}{ Destiny } & Pearson's coefficient & 0.188 & -0.218 & 0.095 & $0.347^{\star}$ & $0.382^{*}$ \\
\hline & P-value & $(0.144)$ & $(0.089)$ & $(0.462)$ & $(0.006)$ & $(0.002)$ \\
\hline \multirow{2}{*}{$\begin{array}{l}\text { The worth of every } \\
\text { single day }\end{array}$} & Pearson's coefficient & 0.142 & 0.008 & 0.138 & 0.207 & 0.217 \\
\hline & P-value & $(0.271)$ & $(0.954)$ & $(0.283)$ & $(0.106)$ & $(0.090)$ \\
\hline \multirow{2}{*}{$\begin{array}{l}\text { Life is synonymous } \\
\text { with value and worth }\end{array}$} & Pearson's coefficient & 0.153 & 0.102 & 0.146 & 0.150 & 0.202 \\
\hline & P-value & $(0.235)$ & $(0.431)$ & $(0.256)$ & $(0.244)$ & $(0.115)$ \\
\hline
\end{tabular}

* Statistical significance at $p<0.05$ on the assumption that the study group constituted a random sample out of a population with similar characteristics. 
res; to change their lifestyle, routine and attach to the treatment, despite being weakened.

Thus, keep the hope while facing the disease is a hard, continuous and important process because it stimulates patients with chronic renal failure and their social support network to seek new solutions or the acceptance of the new condition imposed by the disease. Religiosity, when positively experienced, is a supportive aid and imparts strength to face the difficulties in daily life related to their spiritual beliefs [14].

In this sense, these aspects become essential when it comes to reality of the northeastern hinterlands. Nephrologists and nurses witness spiritual and religious practices during hemodialysis, in which patients perform deep moments of prayer, always seeking divine protection for the condition they are going through. In this environment, it is common for patients to take sacred objects such as the Bible, rosaries, prayer books, pictures or medals with images of saints, which are considered symbols of faith that generate spiritual comfort and maintain the sense of hope [15].

Studies show that patients with chronic renal disease develop signs and symptoms such as fatigue, asthenia, rash, headache, hypertension, hypotension, cramps, malaise, nausea and vomiting [16-17]; restricting the free time and the physical and psychological disposition of the patient, which prevents participation and attendance for prolonged times of celebration. These symptoms are consequence to the limitations imposed by kidney disease, as well as the consequences of hemodialysis.

Still, it is notable that kidney patients, most often, are abandoned by their families due to several hours required for hemodialysis sessions. This abandonment creates negative feelings and frustrations, conflicts and fears related to the treatment. These, in turn, are overcome with the support of faith and religious practices [18]. Therefore, unlike other diseases, practices and religious attitudes are more often practiced in private than in community meetings, in the temple or the church.

As regards the assessment of hope in patients with chronic renal failure undergoing hemodialysis, a study conducted in a Replacement Therapy unit in São Paulo reported a score variation pattern similar to the present study, where the lowest averages were in items 2 and 10, and the items with higher scores were the items 5 and 12 [10]. However, there was a higher level of hope in patients with chronic renal disease in the northeastern hinterlands when compared to other studies conducted in São Paulo. One of such studies included 50 elderly aged between 67 to 73 years with an average of HHS of $36.20( \pm 2.90)[10]$; and the other was carried out with 127 patients aged between 23 and 89 years and the average was 38.06 ( \pm 4.32) [7].

In the meantime, patients with chronic renal disease did not seem to have short and long term plans, and "do not know where they want to go, i.e., don not have sense of direction". Studies show that these behaviors are directly related to the lack of will to live and lack of patience [19]; when these feelings are manifested, they trigger revolt, in which people begin to fail to believe in the only possibility of curative therapy beyond faith: the transplantation. It does not matter how unpredictable is the success, there is always a search for survival without the need for dialysis, because the suffering that this therapy incurs results in losses in many aspects of living. The hope of healing through transplantation emerges as a dream of restart [20].

It appears that the hemodialysis is inevitable, unavoidable and brings direct changes in lifestyle, in its objectives, in family, work, income and body image [21]. Thus, chronic patients can not lose hope, and for this they stick to their faith and/or their religion to redirect their days in search of better quality of life.

In this sense, religion is a belief system full of rituals and symbols that can help the individual to approach and establish contact with the sacred en- 
tity and consequently produce committed and organized practices from the community life [11]. At this point, it is observed that religiosity triggers a new meaning of the search process for ways hitherto experienced, leaning and/or finding comfort through the sacred.

Religiosity in patients with chronic renal failure is marked by many attitudes and practices that are different of those practiced by healthy people. Therefore, non-organizational religiosity is best experienced than the organizational and intrinsic, as patients dedicate more time with private prayers, and consider themselves more religious than what they were before. Still, they start to understand the conflicts and tragedies based on experiences of faith, live moments of religious conversion, mystical experience and transcendence. They gain more knowledge on dogmas and doctrines, generating satisfaction with life and getting a personal meaning for it [22].

A study conducted with patients with chronic renal disease in the state of Paraiba [11] in relation to the religious attitude adopted in face of the hemodialysis treatment found that the individuals who searched for religious knowledge showed better quality of life levels in the psychological $(r=0.21, p$ $<0.05$ ] and social relationship $(r=0.25, p<0.05)$ domains. With regard to religious sentiments adopted in face of the religious attitude, the domains level of autonomy ( $r=0.22, p<0.05)$, the field of social relations $(r=0.22, p<0,05)$ and the environmental area $(r=0.23, p<0.05)$ were correlated.

It is noticed that religiosity in patients with chronic renal failure is a emotional (self-knowledge), instrumental (skills/abilities) and informative (knowledge) support in seeking to achieve a better perspective for the future.

Patients with chronic renal failure were asked about the role of religion in their lives in a study conducted in São Paulo, and $63.1 \%$ of patients believed that religion was very important for their recovery, and $55.8 \%$ said that religion is something necessary for their lives [23].
It is also noted in the present study that religion is a mechanism for solving problems as brings relief, comfort and consolation; and search for meaning to relevant problems of existence, intimacy (I am able to give and receive caring/love), understanding of the self and of the sacred, providing release [11].

Regarding the participation of religious rituals, it is observed that these favor the contact with others. Thus, the involvement in their religious activities contributes to assume roles and functions, providing optimism, making it capable of contributing to others through reception and sharing of affection and love. Thus, when patients attend assiduously religious temples to express or manifest one's religion, there are better levels of functional autonomy $(r=0.28, p<0.01)$ and social relationships $(r=0.22$, $p<0.05)$ [11].

The Religiosity is also a coping mechanism for stressful situations in life, because it facilitates problem solving. In this sense, religious coping is a kind of personal confrontation that uses the sacred as the source for solving problems, which may be positive or negative. In this study we showed that patients with chronic renal failure present a positive coping related to good levels of hope and religiosity through a system of religious beliefs and practices.

Religious coping is a mediator in the health-disease process due to the development of cognitive schemes that may increase the personal resources of hope, by the increased sense of control and self-esteem. This mechanism allows them to assign meaning to stressful events (I have a sense of direction, I am optimistic about life, I feel strong) in search for better days and health.

A study with renal patients in the south of Minas Gerais found that positive religious coping was strongly associated with the time of treatment $(p=$ 0.021 ) and to the importance that individuals give to religion/spirituality in their lives $(p=0.006)$ [24].

We cannot conceive that the absence of hope and religiosity leads to disease, but it is understandable that these may constitute a protective factor 
or a coping aid in the face of daily adversity. It is not necessary nor sufficient for the psychological well-being, but it can lead to a worldview able to help the individual discover the meanings of life.

\section{Study limitations}

The main limitation of this study is that it was held in a unique setting, in addition to the cross-sectional design, which cannot establish a temporal relationship with the variables. Thus, further studies must be conducted in order to identify variables involved with hope and religion to face the health-disease process.

\section{Contributions to the field of nursing}

In this sense, the evaluation of hope in patients with chronic renal failure and their religiosity becomes essential for planning and setting goals to be achieved through nursing interventions. This will improve the coping and reduce the impact of the disease, resulting in better adherence to treatment.

\section{Conclusion}

This study made possible the measurement of hope and religiosity in patients with chronic renal disease in Paraíba hinterlands. The sample showed a high score of hope and religiosity, and a positive correlation of moderate magnitude between the two scales.

Professionals that provide assistance to patients with chronic renal failure undergoing dialysis should be sensitive to consider hope and religiosity at the moment of providing care as a tool to address the health-disease process.

\section{References}

1. Jha V, Garcia-Garcia G, Iseki K, Li Z, Naicker S, Plattner B, et al. Chronic kidney disease: global dimension and perspectives. Lancet. 2013; 382(9888):260-72.

2. Sociedade Brasileira de Nefrologia. Censo de diálise. São Paulo: SBN; 2014

3. Cortez EA, Teixeira ER. O Enfermeiro diante da religiosidade do cliente. Rev Enferm UERJ. 2010; 18(1):114-9.

4. Chaves ECL, Carvalho EC, Dantas RAS, Terra FS, Nogueira DP, Souza L. Validation of Pinto and Pais-Ribeiro's spirituality scale in patients with chronic renal insufficiency in hemodyalisis. Rev Enferm UFPE. 2010; 4(2):715-21.

5. Balsanelli ACS, Grossi SAA, Herth KA. Cultural adaptation and validation of the herth Hope Index for portuguese language: study in patients with chronic illness. Texto Contexto Enferm. 2010; 19(4):754-61

6. Sartore AC, Grossi SAA. Escala de Esperança de Herth Instrumento adaptado e validado para a língua portuguesa. Rev Esc Enferm USP. 2008; 42(2):227-32.

7. Ottaviani AC, Souza EN, Drago NC, Mendiondo MSZ, Pavarini $\mathrm{SCl}$, Orlandi FS. Hope and spirituality among patients with chronic kidney disease undergoing hemodialysis: a correlational study. Rev Latino-Am Enfermagem. 2014; 22(2):248-54.

8. Moreira-Almeida A, Peres MF, Aloe F, Lotufo Neto F, Koenig HG. Versão em português da Escala de Religiosidade da DukeDUREL. Rev Psiq Clín. 2008; 35(1):31-2.

9. Martinez EZ, Santos Almeida RG, Carvalho ACD. Propriedades da Escala de Religiosidade de Duke em uma amostra de pósgraduandos. Rev Psiq Clín. 2012; 39(5):180.

10. Orlandi FS, Pepino BG, Pavarini SCI, Santos DA, Mendiondo MS. The evaluation of the level of hope of elderly chronic kidney disease patients undergoing hemodialysis. Rev Esc Enferm USP. 2012; 46(4):897-901.

11. Nepomuceno FCL, Melo Júnior IM, Silva EA, Lucena KDT. Religiosidade e qualidade de vida de pacientes com insuficiência renal crônica em hemodiálise. Saúde Debate. 2014; 38(100):119-28.

12. Ripamonti Cl, Buonaccorso L, Maruelli A, Bandieri E, Boldini S, Pessi MA, et al. Hope Herth Index (HHI): a validation study in Italian patients with solid and hematological malignancies on active cancer treatment. Tumori. 2012; 98(3):385-92.

13. Wnuk M, Marcinkowski JT, Fobair P. The relationship of purpose in life and hope in shaping happiness among patients with cancer in Poland. J Psychosoc Oncol. 2012; 30(4):461-83.

14. Chaves ECL, Paulino CF, Souza VHS, Mesquita AC, Carvalho FS, Nogueira DA. Qualidade de vida, sintomas depressivos e religiosidade Em idosos: um estudo transversal. Texto Contexto Enferm. 2014; 23(3):648-55.

15. Carvalho CC, Chaves ECL, lunes DH, Simão TP, Grasselli CSM, Braga CG. Effectiveness of prayer in reducing anxiety in cancer patients. Rev Esc Enferm USP. 2014; 48(4):684-90. 
16. Cabral LC, Trindade FR, Branco FMFC, Baldoino LS, Silva MLR, Lago ECA. A percepção dos pacientes hemodialíticos frente à fístula arteriovenosa. Revista Interdisciplinar. 2013; 6(2):15-25.

17. Terra FS, Costa AMDD, Ribeiro CCS, Nogueira CS, Prado JP, Costa MD et al. O portador de insuficiência renal crônica e suas dependências ao tratamento hemodialítico: Compreensão fenomenológica. Revista Brasileira de Clínica Médica, 2010; 8(4), 306-10.

18. Rudnicki T. Doença renal crônica: vivência do paciente em tratamento de hemodiálise. Contextos Clínicos. 2014; 7(1):105116.

19. Andrade SV, Sesso R, Diniz DHMP. Desesperança, ideação suicida e depressão em pacientes renais crônicos em tratamento por hemodiálise ou transplante J Bras Nefrol. 2015; 37(1):55-63

20. Lopes SGR, Silva DMGV. Narrativas de mulheres em hemodiálise: à espera do transplante renal. Texto Contexto Enferm. 2014; 23(3):680-87.

21. Davison SN. End-of-life care preferences and needs: perceptions of patients with chronic kidney disease. Clinical Journal of the American Society of Nephrol. 2010; 5(2),195-204.

22. Aquino TAA, Gouveia VV, Silva SS, Aguiar AA. Escala de Atitudes Religiosas, Versão Expandida (EAR-20): evidências de validade. Aval Psicol. 2013; 12(2):109-19.

23. Lucchetti G, Almeida LGC, Lucchetti ALG. Religiousness, mental health, and quality of life in Brasilian dialysis patients. Hemodialysis International. 2012; 16(1):89-94.

24. Valcanti CC, Chaves ECL, Mesquita AC, Nogueira DA, Carvalho EC. Religious/spiritual coping in people with chronic kidney disease undergoing hemodialysis. Rev Esc Enferm USP. 2012; 46(4):838-45.

Publish in International Archives of Medicine

International Archives of Medicine is an open access journal publishing articles encompassing all aspects of medical science and clinical practice. IAM is considered a megajournal with independent sections on all areas of medicine. IAM is a really international journal with authors and board members from all around the world. The journal is widely indexed and classified Q1 in category Medicine. 